\title{
DOES A CORPORATION ACTING AS TRUSTEE HOLD IN JOINT TENANCY WITH ITS CO-TRUSTEE?
}

The problem of whether or not a corporation acting as a trustee may be a joint tenant with an individual acting as a co-trustee is interesting in view of an apparent static situation in American legal theory.

The general rule is that two or more individuals acting as co-trustees will be treated as joint tenants, and on the death of one, the legal title to the trust property passes to the survivor or survivors. This doctrine has been retained even in jurisdictions which have abolished joint tenancy by statute. ${ }^{2}$ The retention is due to the convenience of the doctrine of survivorship in the administration of trust estates. Corporations, however, have never been considered as capable of holding in joint tenancy with an individual. ${ }^{3}$ The reasons given for this result are that there is no mutual right of survivorship because of the corporation's perpetual life and that there is too great a difference between the legal ownership of the natural person which passes to his heirs and the legal ownership of the corporation with its perpetual succession. ${ }^{4}$

Of the few American decisions on the question of joint tenancy between individuals and corporations the most outstanding are Telfair v. Howe, ${ }^{5}$ and Moore Lumber Co.v. Behrman. ${ }^{6}$ In the first, the testatrix directed her executors to pay the residue of her estate to a corporation and a non-existent society. The court held that since a corporation cannot hold in joint tenancy it could not take the whole and that the testatrix therefore died intestate. In the latter case, A, under contract with a corporation, furnished material and labor in improving property owned by the corporation and $\mathrm{B}$, a natural person. When $\mathrm{A}$ sought to recover from $B$, he failed on the ground that $B$ would be liable only if he held in joint tenancy with the corporation and that a corporation could not hold in joint tenancy either with an individual or another corporation. $\S 343$.

I Daily v. Sherratt, 2 Eq. Cas. Abr. 742 (1738); I Perry, Trusts (7th ed. Baldes, I929), 584,

${ }^{2}$ I Beach, Trusts and Trustees (1897), 217, \& 104; I Perry, stpra note I, 584, $\$ 343$.

3 Angell \& Ames, Corporations (Irth ed. Lathrop, I882), 167, § I85; I Beach, supra note 2, 217, § 104; 4 Thompson, Corporations (3d ed. White, 1927), 45, \& 2457; I Tiffany, Real Property ( 2 d ed. 1920), 625, § I9I.

4 Dewitt v. San Francisco, 2 Cal. 289, 290 (1852); Tiffany, supra note 3. See Bennet v. Holbeck, 2 Wms. Saunders 319, note 4, 85 Eng. Rep. $\mathrm{Irr}_{3}$ (1682) where it is said, "And this jus accrescendi ought to be mutual; which $I$ apprehend to be one reason why neither the king nor any corporation can be a joint tenant with a private person. For there is no mutuality: The private person has not even the remotest chance of being seised of the entirety, by benefit of survivorship, for the king and corporation can never die."

But see Co. Litt. \$280 (Coventry, ed. 183 o), where Coke expressly says that there may be a joint tenancy without equal benefit of survivorship "as if a man lets lands to A and B during the life of A, if B dies A shall have all by the survivor, but if A dies B shall have nothing." See also $\& 296$.

${ }_{5} 3$ Rich. Eq. (S.C.) 235 (185I).

${ }^{3}$ I44 Misc. 29r, 259 N.Y.S. 248 (1932). 
The only authorities relied on in the latter case were Blackstone ${ }^{7}$ and the English case of The Law Guarantee \& Trust Society v. Governor \& Co. of the Bank of England. ${ }^{8}$ The decision in this case was reluctantly reached by a court that felt itself bound by old authority. ${ }^{9}$ As a direct result, Parliament two years later adopted legislation which allowed stock to be transferred to and held in the name of an individual and a corporation which would be treated as holding in joint tenancy with the individual..$^{\text {ro }}$ The question was completely settled in England in 1899 by an act which empowered corporations to hold real and personal property in joint tenancy in the same manner as if they were individuals. ${ }^{\text {Ix }}$

What the view of the American courts would be if the problem were presented in the trust situation is conjectural, but in view of the New York decision, it is quite probable that the old law would be followed. The attitude of the trust companies is varying. Some consider the problem important, while others show a complete lack of interest. It is an almost universal practice, however, to expressly provide in the trust instrument for survivorship in the trust company on the death of the individual co-trustee. ${ }^{12}$

At one time a corporation was not thought capable of acting as a trustee. The lack of conscience in which trust and confidence could be reposed by the settlor, the inability of the court of equity to compel performance because the artificial body of a corporation could have no conscience on which a court of conscience could act, and the impossibility of imprisoning a corporation as a method of enforcing equity's purely personal decrees were thought insurmountable difficulties. ${ }^{13}$ But these technical rules have been overcome. ${ }^{\mathrm{I}}$ The technicalities of joint tenancy do not seem as serious as these, and it is possible that the common law may overcome them without the aid of statute.

Geraldine W. Lutes

72 Bl. Comm. 148

${ }_{24}$ Q.B.D. 406 (189o).

9 Willion v. Berkly, I Plow. 223, 75 Eng. Rep. 339 (I562); Bennet v. Holbeck, supra note 4. ${ }^{{ }^{0}} 55 \& 56$ Vict. c. $39, \S 26$.

II Bodies Corporate Act, $62 \& 63$ Vict. c. 20 . See In re Thompson's Settlement Trusts, [1905] I Ch. 229; Godefroi, Trusts \& Trustees (4th ed. Williams, I9r5), 496.

${ }^{12}$ The following is a typical trust deed provision for survivorship in the corporation. "Upon the death, resignation, refusal or inability of. to act as Trustee hereunder, the Trust Company shall have, as sole Trustee, all title, rights, powers, duties, discretions and obligations herein conferred upon and vested in said Trustees jointly."

${ }_{3}$ Perry, Trusts, szipra note $2, \S 42$; Lewin, Trusts ( 2 th ed. Dale \& Streeton $x 9 x$ ), 2.

${ }^{14}$ Perry, supra note $2,3 \mathrm{r}, \S 42$; Lewin, supra note $\mathrm{r}_{3}, 7$. 